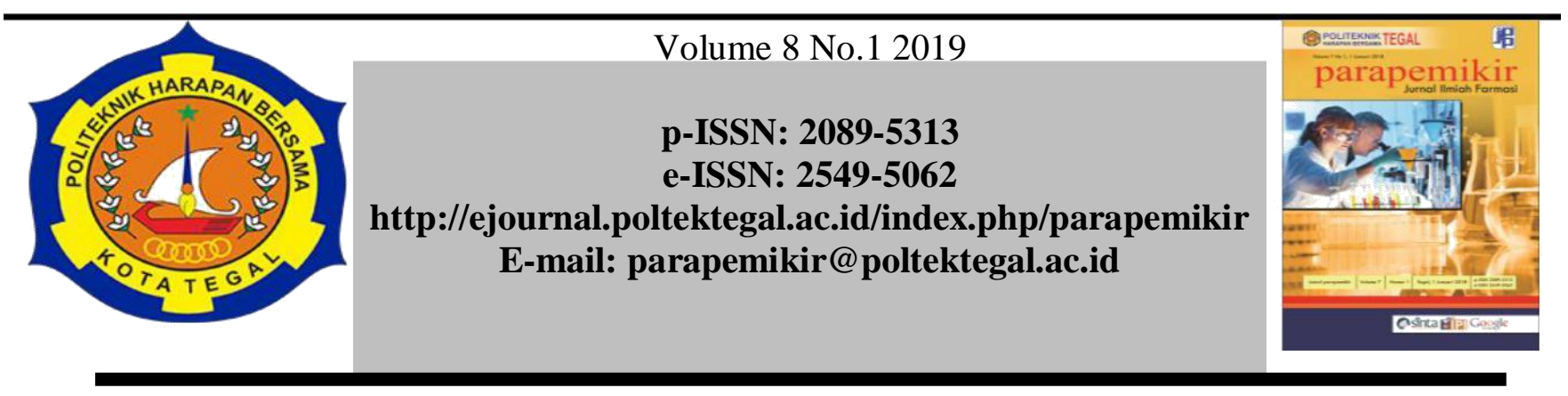

\title{
WAKTU TUNGGU PELAYANAN RESEP DI DUA PUSKESMAS KABUPATEN TEGAL
}

\author{
Adila Prabasiwi*1, Sari Prabandari ${ }^{2}$, Arda Kusuma Dewi ${ }^{3}$, Oktaviani Nihlatuzzahroh ${ }^{4}$ \\ 1,2,3,4 Prodi DIII Farmasi,Politeknik Harapan Bersama Tegal, Indonesia \\ Email : adilaprabasiwi@gmail.com
}

\begin{tabular}{|c|c|}
\hline Article Info & Abstrak \\
\hline Article history: & \multirow{10}{*}{$\begin{array}{l}\text { Waktu tunggu pelayanan resep merupakan salah satu faktor yang menyebabkan } \\
\text { ketidakpuasan pasien. Penelitian ini bertujuan untuk mengetahui lama waktu tunggu } \\
\text { pelayanan resep di dua Puskesmas terpilih di Kabupaten Tegal. Penelitian ini termasuk } \\
\text { dalam penelitian deskriptif dengan pendekatan kuantitatif. Penelitian dilakukan di dua } \\
\text { Puskesmas terpilih. Sampel merupakan resep yang dilayani di instalasi farmasi pada } \\
\text { bulan Februari berjumlah } 200 \text { resep dengan metode quota sampling. Data waktu tunggu } \\
\text { diambil dengan menggunakan alat stopwatch. Analisis data menggunakan analisis } \\
\text { univariat dan bivariat. Analisis univariat dengan menggambarkan waktu tunggu } \\
\text { keseluruhan, sedangkan analisis bivariat menggunakan t-test untuk melihat perbedaan } \\
\text { waktu tunggu. Hasil penelitian menunjukkan bahwa terdapat perbedaan rata-rata waktu } \\
\text { tunggu untuk obat jadi dan obat racik ( } \mathrm{p}=0,000 \text { ). Rata-rata waktu tunggu pelayanan } \\
\text { resep untuk obat jadi adalah } 9 \text { menit } 5 \text { detik, untuk obat racik } 17 \text { menit } 28 \text { detik. } \\
\text { Terdapat perbedaan waktu tunggu pelayanan resep untuk obat jadi dan obat racik } \\
\text { antara Puskesmas X dengan Puskesmas Y ( } \mathrm{p}=0,000 \text { ). Waktu tunggu pelayanan resep di } \\
\text { Puskesmas X adalah } 14 \text { menit } 45 \text { detik (obat jadi) dan } 21 \text { menit } 3 \text { detik (obat racik). } \\
\text { Waktu tunggu pelayanan resep di Puskesmas Y adalah } 5 \text { menit } 5 \text { detik (obat jadi) dan } \\
10 \text { menit } 25 \text { detik (obat racik).. }\end{array}$} \\
\hline $\begin{array}{l}\text { Received Desmber } \\
2018\end{array}$ & \\
\hline Received in & \\
\hline revised form & \\
\hline Desember 2018 & \\
\hline Accepted Januari & \\
\hline 2019 & \\
\hline Available online & \\
\hline January 2019 & \\
\hline $\begin{array}{l}\text { Kata kunci: waktu } \\
\text { tunggu, resep, obat } \\
\text { jadi, obat racik, } \\
\text { puskesmas. }\end{array}$ & \\
\hline & abstract \\
\hline $\begin{array}{l}\text { Keywords: } \\
\text { Dispensary waiting } \\
\text { time, recipes, non } \\
\text { concoction recipe, } \\
\text { concoction recipe, } \\
\text { puskesmas. }\end{array}$ & $\begin{array}{l}\text { Dispensary waiting time is one of the factors that causes patient dissatisfaction. This } \\
\text { study aims to determine the waiting time for prescription services in two selected } \\
\text { Puskesmas in Tegal Regency. } \\
\text { This research was included in a descriptive study with a quantitative approach. The } \\
\text { study was conducted in two selected Puskesmas in Tegal Regency. The sample is a } \\
\text { recipe that was served in a pharmaceutical installation in February totaling } 200 \text { recipes } \\
\text { using the quota sampling method. Dispensary waiting time is taken using a stopwatch } \\
\text { tool. Data analysis using univariate and bivariate analysis. Univariate analysis by } \\
\text { describing the overall waiting time, while bivariate analysis uses a t-test to see the } \\
\text { difference in dispensary waiting time. } \\
\text { The results showed that there were differences in the average waiting time for non } \\
\text { concoction recipe)and concoction recipe (p }=0,000 \text { ). The average dispensary waiting } \\
\text { time for non concoction is } 9 \text { minutes } 5 \text { seconds, for concoction drugs } 17 \text { minutes } 28 \\
\text { seconds. There is a difference in dispensary waiting time for non concoction and } \\
\text { concoction drugs between Puskesmas X and Puskesmas Y (p }=0,000 \text { ). The waiting } \\
\text { time for prescription services at Puskesmas X is } 14 \text { minutes } 45 \text { seconds (non } \\
\text { concoction recipe) and } 21 \text { minutes } 3 \text { seconds (concoction recipe). The dispensary } \\
\text { waiting time at Puskesmas Y is } 5 \text { minutes } 5 \text { seconds (non concoction recipe) and } 10 \\
\text { minutes } 25 \text { seconds (concoction recipe) }\end{array}$ \\
\hline
\end{tabular}


Adila Prabasiwi, Sari Prabandari, Arda Kusuma Dewi dan Oktaviani Nihlatuzzahroh, Vol 8 (1) 2019 pp 41-46

Alamat korespondensi:

Prodi DIII Farmasi Politeknik Harapan Bersama Tegal

Gedung A Lt.3. Kampus 1

J1. Mataram No. 09 Kota Tegal, Kodepos 52122

Telp. (0283) 352000

p-ISSN: 2089-5313

E-mail: parapemikir_poltek@yahoo.com

e-ISSN: 2549-5062 


\section{Pendahuluan}

Salah satu institusi yang menyelenggarakan pelayanan kefarmasian adalah puskemas. Pelayanan kefarmasian di puskesmas merupakan satu kesatuan yang tidak terpisahkan dari pelaksanaan upaya kesehatan, yang berperan penting dalam meningkatkan mutu pelayanan kesehatan bagi masyarakat. ${ }^{1}$ Mutu pelayanan kesehatan menunjuk pada tingkat kesempurnaan pelayanan kesehatan yang dapat menimbulkan kepuasan pada pasien. ${ }^{2}$

Kepuasan pasien dapat dilihat dari berbagai indikator salah satunya adalah kecepatan pelayanan resep. ${ }^{3}$ Kecepatan pelayanan diukur melalui waktu tunggu. Waktu tunggu dapat dijadikan indikator untuk mengetahui seberapa profesionalisme staf Istalasi Farmasi yang ditunjukkan dalam keterampilan melayani resep. Waktu tunggu merupakan masalah yang sering menimbulkan keluhan pasien di beberapa Puskesmas. $^{4}$

Berbagai penelitian menunjukkan adanya hubungan antara waktu tunggu pelayanan resep dengan tingkat kepuasan pasien. Pelayanan resep yang lama akan menurunkan tingkat kepuasan pasien dalam hal waktu tunggu pelayanan. Tetapi, pelayanan resep yang cepat akan meningkatkan kepuasan pasien dalam hal waktu tunggu pelayanan. ${ }^{5}$ Waktu penyelesaian resep dokter pada pasien rawat jalan yang paling memberikan jaminan kepuasan adalah kurang dari 13 menit. $^{6}$

Salah satu sasaran kinerja Puskesmas di Kabupaten Tegal yang disesuaikan dengan Perbup No. 23 tahun 2014 tentang standar Pelayanan Minimal Puskesmas di Kabupaten tegal yaitu waktu tunggu untuk obat jadi $<30$ menit dan untuk obat racik $<60$ menit. ${ }^{7}$ Standar ini dibuat untuk meningkatkan mutu pelayanan kefarmasian di puskesmas.

Hasil dari beberapa penelitian menunjukkan bahwa waktu tunggu pelayanan resep masih lama atau belum sesuai standar pelayanan minimal yang ditetapkan. Berdasarkan hasil penelitian di Semarang, $78 \%$ resep non racikan tidak mencapai standar. ${ }^{8}$ Penelitian di Rumah Sakit di Surakarta menunjukkan bahwa waktu tunggu pasien rawat jalan dengan pelayanan obat jadi terdapat $57,5 \%$ pelayanan resep yang melebihi standar. ${ }^{9}$ Penelitian di Surabaya menunjukkan waktu lama tunggu pelayanan resep non racikan mempunyai presentase $0 \%$ sesuai standar dan obat dengan presentase $67 \%$ sesuai dengan standar. ${ }^{10}$

Beberapa penelitian terkait waktu tunggu pelayanan resep yang sudah dipublikasikan, dilakukan di unit pelayanan kesehatan rumah sakit dan apotek. Penelitian mengenai waktu tunggu pelayanan resep di Puskesmas belum banyak dilakukan. Berdasarkan pertimbangan tersebut, penelitian ini bertujuan untuk menghitung rata-rata lama waktu tunggu pelayanan resep di dua puskesmas di Kabupaten Tegal

II. Metodologi Penelitian

Penelitian ini termasuk dalam penelitian deskriptif dengan pendekatan kuantitatif. Penelitian dilakukan di dua Puskesmas terpilih di Kabupaten Tegal pada bulan Januari 2018.

Populasi pada penelitian ini adalah semua resep yang dilayani di ruang farmasi di dua Puskesmas pada bulan Januari 2018. Jumlah populasi dalam penelitian ini belum diketahui sebelumnya.

Penentuan jumlah sampel menggunakan rumus dasar perhitungan sampel estimasi proporsi (Levy \& Lemesshow, 1999) yaitu sebagai berikut :

$$
\mathrm{n}=\frac{z_{1-\pi / 2^{*}}^{2} p^{*}(1-p)}{d^{2}}
$$

Keterangan:

$\mathrm{n}=$ Jumlah sampel minimal

$\mathrm{Z}_{1-\mathrm{a} / 2}=$ Derajat kemaknaan. $(1,960)$

$\mathrm{P}=$ Proporsi Resep $(0,5)$

$\mathrm{d}=$ Tingkat presisi/ deviasi $(0,1)$

Berdasarkan perhitungan tersebut, maka diperoleh jumlah sampel minimal yang harus dipenuhi sebesar 96 resep untuk 1 puskesmas. Karena ada dua puskesmas maka jumlah sampel dikali dua dan dibulatkan menjadi 200 resep untuk memudahkan perhitungan.

Setelah ditentukan jumlah sampel minimal, ditentukan cara pengambilan sampel yaitu dengan metode quota sampling. Pengambilan resep juga didasarkan pada kriteria inklusi dan ekslusi. Adapun kriteria inklusi dalam penelitian antara lain:

a. Resep pasien rawat jalan

b. Resep obat racikan dan non racikan

c. Satu lembar resep obat racikan adalah resep yang hanya terdiri dari obat racik atau gabungan obat jadi dan obat racik.

d. Satu lembar resep obat non racikan adalah resep yang hanya terdiri dari obat jadi.

Untuk kriteria ekslusi dalam penelitian antara lain:

a. Resep pegawai Puskesmas

b. Resep obat yang tidak bisa dipenuhi atau stok habis

c. Resep yang dilayani oleh mahasiswa PKL.

Alat yang digunakan untuk pengumpulan data waktu tunggu berupa formulir waktu tunggu, stopwatch dan alat tulis. Peneliti melakukan pengamatan langsung resep pasien Pengumpulan data dilakukan selama dua hari pada pukul 08.3012.00. Pengamatan yang dilakukan mulai dari proses penerimaan resep hingga penyerahan obat yang dibagi menjadi komponen tindakan yaitu ketika resep dikerjakan petugas, serta komponen delay yaitu saat resep diletakkan menunggu untuk dikerjakan. untuk dapat menghitung jumlah kedatangan resep dan jumlah resep yang telah dilayani, maka resep yang masuk ke loket di beri 
nomor urut, mencatat nama pasien, dan mencatat jam datang (jam menyerahkan resep) serta jam pulang (jam mendapatkan obat). Selain itu, peneliti juga menyalakan stopwatch untuk mengetahui jangka waktu tunggu pelayanan resep. Setiap resep yagg telah diberi tanda waktu mulai pelayanan dan waktu selesai pelayanan, dengan demikian dapat ditentukan jangka waktu tunggu pelayanan resep obat jadi dan resep obat racikan. Hasil pengukuran waktu tunggu tersebut akan dicatat ke dalam formulir waktu tunggu.

Analisis data menggunakan analisis univariat dan bivariat. Analisis univariat dengan menggambarkan waktu tunggu keseluruhan, sedangkan analisis bivariat menggunakan t-test untuk melihat perbedaan waktu tunggu antara obat jadi dan obat racik serta melihat waktu perbedaan antara dua puskesmas.

\section{HASIL DAN PEMBAHASAN}

Dari hasil pengumpulan data diperoleh jumlah sebanyak 200 resep yang terdiri dari obat jadi dan resep obat racik. Dari 200 resep, proporsi terbanyak adalah resep obat jadi dibandingkan obat racik. Obat jadi berjumlah $60,5 \%$ (121 resep), sedangkan obat racik berjumlah $39,5 \%$ (79 resep).

Tabel 1. Proporsi Resep Berdasarkan Jenis Obat

\begin{tabular}{lll}
\multicolumn{1}{c}{ Jenis Obat } & \multicolumn{1}{c}{ n } & \multicolumn{1}{c}{$\%$} \\
\hline Obat Jadi & 121 & 60,5 \\
Obat Racik & 79 & 39,5 \\
Jumlah & 200 & $100 \%$ \\
\hline
\end{tabular}

Berdasarkan hasil pengamatan dan wawancara dengan Apoteker dan Tenaga Teknis Kefarmasian di Puskesmas, jumlah resep obat racikan lebih sedikit dibandingkan dengan resep obat jadi. Hal ini dikarenakan pasien anak-anak jumlahnya lebih sedikit daripada jumlah pasien orang dewasa. Resep untuk anak sebagian besar merupakan resep obat racikan.

Untuk waktu tunggu pelayanan resep, diperoleh hasil bahwa waktu tunggu pelayanan resep obat jadi lebih cepat dari pada waktu tunggu resep obat racik. Rata-rata waktu tunggu pelayanan resep untuk obat jadi adalah 9 menit 5 detik (Standar Deviasi= 5 menit 33 detik), untuk obat racik 17 menit 28 detik (Standar Deviasi= 5 menit 42 detik). Hasil analisis dengan menggunakan uji independent sample t- test diperoleh nilai p sebesar 0,000 yang berarti terdapat perbedaan rata-rata waktu tunggu untuk obat jadi dan obat racik. Tabel 2. Perbedaan Waktu Tunggu Obat Jadi dan Obat Racik

\begin{tabular}{|c|c|c|c|c|c|}
\hline $\begin{array}{l}\text { Jenis } \\
\text { Obat }\end{array}$ & Mean & SD & SE & $\begin{array}{c}P \\
\text { value }\end{array}$ & $\mathbf{N}$ \\
\hline $\begin{array}{l}\text { Obat } \\
\text { Jadi }\end{array}$ & 0:09:05 & $0: 05: 33$ & $0: 00: 30$ & 0,000 & 121 \\
\hline $\begin{array}{l}\text { Obat } \\
\text { Racik }\end{array}$ & $0: 17: 28$ & $0: 05: 42$ & $0: 00: 38$ & & 79 \\
\hline
\end{tabular}

Obat jadi adalah obat dalam keadaan murni atau campuran dalam bentuk serbuk, cairan, salep, tablet, pil, supositoria atau bentuk lain yang mempunyai nama teknis sesuai dengan Farmakope Indonesia atau buku lain. ${ }^{11}$ Obat racik adalah obat yang dibuat melalui proses peracikan. Peracikan obat adalah proses menggabungkan, mencampur, atau mengubah bahan untuk membuat obat yang disesuaikan dengan kebutuhan masing-masing pasien. Peracikan mencakup kombinasi dari dua atau lebih obat. $^{12}$

Waktu tunggu pelayanan obat racikan lebih lama dibandingkan dengan pelayanan resep obat jadi atau non racikan karena obat racikan memerlukan waktu yang lebih, tidak hanya mempersiapkan obat tetapi juga perlu perhitungan dosis obat, penimbangan bahan obat, serta melakukan peracikan baik dalam bentuk puyer, kapsul dan sediaan lainnya. Beberapa penelitian menunjukkan lama waktu tunggu pelayanan resep obat jadi lebih cepat dibandingkan pelayanan resep obat racik. ${ }^{13}$

Apabila dilihat dari Standar Pelayanan Minimal untuk rata-rata obat jadi dan obat racikan yang dalam Peraturan Bupati Tegal Nomor 23 Tahun 2014, pelayanan resep baik obat jadi maupun obat racikan di dua Puskesmas tersebut sudah memenuhi standar yaitu lama waktu tunggu obat jadi $\leq 30$ menit sedangkan lama waktu tunggu untuk obat racikan adalah $\leq 60$ menit.

Analisis selanjutnya adalah membandingkan waktu tunggu obat jadi dan obat racik antara dua puskesmas. Berikut hasil perbedaan waktu tunggu pelayanan resep antara dua puskesmas.

Tabel 3. Perbedaan Waktu Tunggu Pelayanan Resep antara Dua Puskesmas

\begin{tabular}{lccccc} 
Puskesmas & Mean & SD & SE & $\begin{array}{c}\text { P } \\
\text { value }\end{array}$ & N \\
& & & & & \\
\hline $\begin{array}{l}\text { Obat Jadi } \\
\text { Puskesmas }\end{array}$ & $0: 14: 45$ & $0: 04: 08$ & $0: 00: 35$ & 0,000 & 50 \\
$\begin{array}{l}\text { X } \\
\text { Puskesmas }\end{array}$ & $0: 05: 05$ & $0: 01: 22$ & $0: 00: 09$ & & 71 \\
$\begin{array}{l}\text { Y } \\
\text { Obat Racik }\end{array}$ & & & & & \\
$\begin{array}{l}\text { Puskesmas } \\
\text { X }\end{array}$ & $0: 21: 34$ & $0: 01: 53$ & $0: 00: 15$ & 0,000 & 50 \\
$\begin{array}{l}\text { Puskesmas } \\
\text { Y }\end{array}$ & $0: 10: 25$ & $0: 01: 40$ & $0: 00: 18$ & & 29 \\
\hline
\end{tabular}

Terdapat perbedaan waktu tunggu pelayanan resep untuk obat jadi dan obat racik antara Puskesmas X dengan Puskesmas Y. Waktu tunggu pelayanan resep di Puskesmas $\mathrm{X}$ adalah 14 menit 45 detik (obat jadi) dan 21 menit 3 detik (obat racik). Waktu tunggu pelayanan resep di Puskesmas $\mathrm{Y}$ adalah 5 menit 5 detik (obat jadi) dan 10 menit 25 detik (obat racik). Hasil uji t test diperoleh nilai $\mathrm{p}=0,000$ yang berarti terdapat perbedaan yang signifikan.

Banyak faktor yang mempengaruhi waktu tunggu pelayanan resep. Faktor pertama adalah jumlah petugas Instalasi Farmasi. ${ }^{14}$ Kedua, jumlah obat yang dibuat serta banyak tidaknya resep yang masuk mempengaruhi waktu tunggu pelayanan resep. ${ }^{9}$ Ketiga adalah sarana dan prasarana termasuk penggunaan teknologi komputer dalam pelayanan resep. ${ }^{15}$

Jumlah petugas mempengaruhi waktu tunggu pelayanan resep. Jika jumlah petugas yang memberikan pelayanan kefarmasian kurang, maka akan memperlama proses pelayanan. Berdasarkan hasil pengamatan yang dilakukan, jumlah petugas yang memberikan pelayanan resep di Puskesmas Y 
lebih banyak dibandingkan Puskesmas X. Di Puskesmas $\mathrm{Y}$ terdapat 1 apoteker dan 5 asisten apoteker, sedangkan di Puskesmas $\mathrm{X}$ hanya terdapat 1 apoteker dan 3 asisten apoteker.

Faktor kedua yang mempengaruhi waktu tunggu adalah jumlah obat yang dibuat serta banyak tidaknya resep yang masuk mempengaruhi waktu tunggu pelayanan resep. Semakin banyak jumlah komponen obat dalam satu resep serta semakin banyak resep yang masuk pada waktu yang hampir bersamaan maka semakin lama pula petugas farmasi dalam melayani resep obat jadi. Sebaliknya, bila jumlah resep yang masuk sedikit dan jumlah komponen obat dalam satu resep sedikit maka semakin cepat petugas farmasi dapat melayani resep obat jadi. Resep yang menumpuk menjadi faktor penentu obat lama diserahkan pada pasien rawat jalan. ${ }^{9}$ Penelitian di Batu menunjukkan bahwa dengan 1-2 macam obat waktu tunggu pelayanan resepnya adalah 14 menit, 3-5 macam obat 19 menit, $\geq 6$ macam obat 28 menit. Hasil tersebut menunjukkan semakin banyak jumlah obat dalam satu resep, semakin panjang waktu tunggu pelayanan obat. ${ }^{14}$ Penambahan item obat di dalam resep akan memberikan penambahan waktu pada setiap tahap pelayanan resep. ${ }^{16}$

Faktor lain yang mempengaruhi lamanya waktu tunggu adalah sarana dan prasarana termasuk penggunaan teknologi komputer dalam pelayanan resep. Resep elektronik dapat meminimalkan risiko pada fase prescribing dan transcribing dan mengurangi waktu tunggu. Ruang pelayanan obat yang sempit menambah lamanya waktu tunggu pelayanan obat. ${ }^{15}$

Berdasarkan hasil pengamatan yang dilakukan di Puskesmas X, luas ruang pelayanan farmasi masih kurang luas untuk pelayanan resep, ruangan menjadi lebih sempit dikarenakan ruang peracikan menjadi satu ruangan dengan gudang farmasi. Sedangkan untuk prasarana yang tersedia terdiri dari satu unit komputer, satu unit printer, tiga buah meja, rak penyimpanan obat, peralatan peracikan obat (dua unit stemper \& mortal, pembungkus kertas puyer). Untuk bagian penerimaan resep hanya terdapat satu komputer dan satu unit printer, dimana komputer dan printer tidak dapat digunakan untuk keperluan entry data serta mengeluarkan print out. Awal bulan Januari sudah mulai menggunakan e-resep, belum bisa diterapkan di pelayanan farmasi karena program komputer yang belum sempurna, hal ini yang mengakibatkan beberapa pekerjaan yang dikerjakan secara manual.

Berbeda dengan hasil pengamatan yang dilakukan di Puskesmas Y, Sarana yang ada di Instalasi Farmasi Puskesmas $\mathrm{Y}$ terdiri dari ruang tunggu pasien yang memadai, loket penerimaan resep yang terpisah dengan loket penyerahan obat, dan ruang peracikan yang luas, sedangkan prasarana yang ada di PuskesmasY terdiri dari perangkat dan program komputer.

\section{KESIMPULAN}

Hasil penelitian menunjukkan bahwa terdapat perbedaan rata-rata waktu tunggu untuk obat jadi dan obat racik $(\mathrm{p}=0,000)$. Rata-rata waktu tunggu pelayanan resep untuk obat jadi adalah 9 menit 5 detik, untuk obat racik 17 menit 28 detik. Terdapat perbedaan waktu tunggu pelayanan resep untuk obat jadi dan obat racik antara Puskesmas $\mathrm{X}$ dengan Puskesmas $\mathrm{Y}(\mathrm{p}=0,000)$. Waktu tunggu pelayanan resep di Puskesmas $\mathrm{X}$ adalah 14 menit 45 detik (obat jadi) dan 21 menit 3 detik (obat racik). Waktu tunggu pelayanan resep di Puskesmas Y adalah 5 menit 5 detik (obat jadi) dan 10 menit 25 detik (obat racik).

\section{UCAPAN TERIMAKASIH}

Terimakasih penulis ucapkan kepada Politeknik Harapan Bersama yang telah memberikan bantuan dana penelitian. Selain itu kepada pihak Puskesmas yang telah memberikan ijin penelitian.

\section{REFERENSI}

[1] Menteri Kesehatan. Peraturan Menteri Kesehatan Republik Indonesia Nomor 74 Tahun 2016 tentang Standar Pelayanan Kefarmasian di Puskesmas. Kemenhum dan HAM; 2016.

[2] Anief Moh. Pengantar Administrasi Kesehatan. Tangerang: Binarupa Aksara; 2010.

[3] Yuniar Y, Handayani RS. Kepuasan Pasien Peserta Program Jaminan Kesehatan Nasional terhadap Pelayanan Kefarmasian di Apotek. Jurnal Kefarmasian Indonesia [Internet]. 8 September 2016;6(1): 39-48. Tersedia pada:

http://ejournal.litbang.kemkes.go.id/index. php/jki/article/view/5468

[4] Razak A, Pamudji G, Harsono M. Analisis Efisiensi Pengelolaan Obat Pada Tahap Distribusi dan Penggunaan di Puskesmas. Jurnal Manajemen dan Pelayanan Farmasi. September 2012;2(3):186-94.

[5] Nurjanah I, Maramis FRR, Engkeng S. Hubungan Antara Waktu Tunggu Pelayanan Resep dengan Kepuasan Pasien di Apotek Pelengkap Kimia Farma Blu PROF. DR. R.D. Kandou Manado.Pharmacon Jurnal Ilmiah Farmasi. Februari 2016;5(1):362-370

[6] Rusdiana N, Wijayanti R, Wahyuni S. Kualitas Pelayanan Farmasi Berdasarkan Waktu Penyelesaian Resep Di Rumah Sakit. Pharmaciana. 30 November 2015; 5 (2): 169-176. Tersedia pada: http://journal.uad.ac.id/index.php/PHARM ACIANA/article/view/2439

[7] Bupati Tegal. Peraturan Bupati Nomor 23 Tahun 2014 tentang Standar Pelayanan Minimal Pusat Kesehatan Masyarakat di Kabupaten Tegal. Sekretaris Daerah Kabupaten Tegal; 2014. 
[8] Purwandari NK, Suryoputro A, Arso SP. Analisis Waktu Tunggu Pelayanan Resep Pasien Rawat di Depo Farmasi Gedung MCEB RS Islam Sultan Agung Semarang. Jurnal Kesehatan Masyarakat. Januari 2017;5(1):103-10. Tersedia pada: http://ejournal-s1.undip.ac.id/index.php/jkm

[9] Suripto DA. Gambaran Pengetahuan, Masa Kerja Petugas dan Waktu Tunggu Pasien Rawat Jalan di Instalasi Farmasi RSUD Surakarta Tahun 2013 [Skripsi]. [Surakarta]: Universitas Muhammadiyah Surakarta; 2013.

[10] Margiluruswati P. Analisis Ketepatan Waktu Tunggu Pelayanan Resep Pasien JKN Dengan Standar Pelayaan Minimal Rumah Sakit 2017. Jurnal Manajemen Kesehatan Yayasan RSDr Soetomo. 30 Oktober 2017 ;3(1):115-126. Tersedia pada: http://jurnal.stikesyrsds.ac.id/index.php/JMK/article/view/84

[11]Anief M. Ilmu Meracik Obat: Teori dan Praktik. Yogyakarta: Gadjah Mada University Press.;

[12] Research C for DE and. Compounding Compounding and the FDA: Questions and Answers [Internet]. [dikutip 29 Oktober
2018]. Tersedia pada: https://www.fda.gov/drugs/guidancecompl ianceregulatoryinformation/pharmacycom pounding/ucm339764.htm

[13] Karuniawati dkk. Evaluasi Pelaksanan Standar Pelayanan Minimal (SPM) Farmasi Kategori Lama Waktu Tunggu Pelayanan Resep Pasien Rawat Jalan Di RSUD Kota Salatiga. Kartika-Jurnal Ilmiah Farmasi. Juni 2016. 4 (1): 20-25.

[14]Megawati, Hakim L, Irbantoro D. Penurunan waktu Tunggu Pelayanan Obat Rawat Jalan Instalasi Farmasi Rumah Sakit Baptis Batu. 2015. Jurnal Kedokteran Brawijaya. 28(2) 163-168.

[15] Kusumarini P, Dwiprahasto I, Wardani PE. Penerimaan Dokter dan Waktu Tunggu Pada Peresepan Elektronik dibandingkan Peresepan Manual. Jurnal Manajemen Pelayanan Kesehatan. September 2011 . 14 (03): 133 - 138

[16] Widiasari,E. Analisa Waktu Pelayanan Resep di Instalasi Farmasi Rawat Jalan RS Tugu Ibu Depok Tahun 2009. Skripsi. Depok: Universitas Indonesia. 2009. 